\title{
Synthesis and Evaluation of Disubstituted Benzimidazole Derivatives as Potential Analgesic and Antidiarrheal Agents
}

\author{
POUSHALI SAHA, SHEJUTI RAHMAN BRISHTY AND S. M. ABDUR RAHMAN* \\ Department of Clinical Pharmacy and Pharmacology, Faculty of Pharmacy, University of Dhaka, Dhaka-1000, Bangladesh
}

Saha et al.: Synthesis and Biological Evaluation of Disubstituted Benzimidazoles

\begin{abstract}
The present study is aimed at the synthesis and biological evaluation of a variety of disubstituted benzimidazole derivatives. The disubstituted benzimidazoles, identified as $3 \mathrm{a}, 3 \mathrm{~b}, 3 \mathrm{c}$, and $3 \mathrm{~d}$ were synthesized through condensation of o-phenylenediamine compounds with aromatic aldehydes in the presence of ammonium salt as a catalyst and characterized by infrared spectroscopy and 1H nuclear magnetic resonance spectra. The compounds were screened for analgesic and antidiarrheal activities using acetic acid-induced writhing and castor oil-induced diarrhea models, respectively in Swiss mice. Compounds 3c, 3a, and $3 \mathrm{~b}$ at a dose of $25 \mathrm{mg} / \mathrm{kg}$ decreased the number of writhes by $88.81,69.40$ and $64.93 \%$, respectively $(\mathrm{P}<0.05)$ as compared to standard aceclofenac $(88.81 \%)$. Derivatives $3 \mathrm{~d}$ and $3 \mathrm{a}$ displayed promising antidiarrheal activity $(\mathrm{P}<0.05)$ at both 25 (inhibition of defecation 67.64 and $56.45 \%$, respectively) and $50 \mathrm{mg} / \mathrm{kg}$ dose levels (80.65 and $75.81 \%$ inhibition respectively) in comparison to standard loperamide (85.48 \% inhibition at a dose of $25 \mathrm{mg} / \mathrm{kg})$. Among the synthesized derivatives, 3a emerged as the most effective analgesic and antidiarrheal agent, and it might be employed as a lead compound for future investigation.
\end{abstract}

Key words: Synthesis, disubstituted benzimidazole, analgesic activity, antidiarrheal activity, writhing inhibition, inhibition of defecation

Heterocyclic compounds occupy a very prominent place as drug molecules by virtue of their diverse biological profiles. Among the wide variety of heterocycles that have been explored in recent years for developing new pharmaceuticals, benzimidazole and its substituted derivatives carry special significance because of their biological and pharmaceutical applications ${ }^{[1]}$. Among the substituted benzimidazole derivatives, disubstituted benzimidazolesareendowed withvariedpharmacological properties among which antimicrobial ${ }^{[2,3]}$, antiviral ${ }^{[4]}$, analgesic and antiinflammatory ${ }^{[5,6]}$, antioxidant ${ }^{[7,8]}$, anticancer $^{[9,10]}$, antitubercular ${ }^{[11]}$, antiparasitic ${ }^{[12,13]}$, antihypertensive ${ }^{[14,15]}$, antidiabetic ${ }^{[16,17]}$, anticonvulsant ${ }^{[18]}$ and thrombin inhibitory property ${ }^{[19]}$ are most prominently reported in the literature. Inspired by these findings, many research groups around the world have employed different synthetic procedures in recent times to obtain disubstituted benzimidazole derivatives as primary products and assessed their biological activities ${ }^{[20-25]}$. However, many of these derivatives are yet to be evaluated for their scope as

*Address for correspondence

E-mail: smarahman@du.ac.bd

March-April 2020 pharmaceutical agents. Besides, some of these methods displayed several limitations including the use of high temperature, harsh acidic condition, low yield and the production of monosubstituted benzimidazoles as byproducts $^{[26,27]}$. In order to overcome these limitations, a synthetic approach has been employed involving the condensation between $o$-phenylenediamines and aromatic aldehydes to selectively produce 1,2-disubstituted benzimidazole derivatives with good yield and also as major products over their monosubstituted counterparts. Initially a number of pharmacological activities of these synthesized derivatives were screened among which the analgesic and antidiarrheal properties were most significantly

This is an open access article distributed under the terms of the Creative Commons Attribution-NonCommercial-ShareAlike 3.0 License, which allows others to remix, tweak, and build upon the work non-commercially, as long as the author is credited and the new creations are licensed under the identical terms

Accepted 10 January 2020

Revised 12 December 2019

Received 26 October 2019

Indian J Pharm Sci 2020;82(2):222-229 
exhibited. The management of pain has traditionally involved the use of nonsteroidal antiinflammatory drugs (NSAIDs), selective cyclooxygenase-2 (COX2) inhibitors, glucocorticoids and immunosuppressive agents. However, long-term use of these classes of drugs often given rise to a variety of side effects including gastrointestinal ulceration, cardiovascular, hepatic and renal toxicity and platelet dysfunction ${ }^{[28,29]}$. To overcome these adverse effects associated with the classical treatment, a lot of efforts have been made to develop new analgesic and antiinflammatory agents with less toxicity and improved therapeutic profile. Benzimidazole is one of the most widely explored heterocyclic moieties to develop such pharmaceutical agents. Gaba et al. provided a comprehensive overview about the antiinflammatory and analgesic properties of a variety of benzimidazole derivatives acting on different therapeutic targets such as COX enzyme, cannabinoid receptors, transient receptor potential vanilloid-1 (TRPV-1) ion channels, bradykinin receptors, some specific cytokines and 5-lipoxygenase activating protein (FLAP) ${ }^{[30]}$. Bezitramide, a benzimidazole based compound was introduced as an oral narcotic analgesic in the early 1970 s to treat chronic and severe pain $^{[31,32]}$. Meijer et al. reported its therapeutic efficacy against experimentally-induced pain and also the pharmacokinetic profile of the parent compound and its hydrolysis product, despropionylbezitramide ${ }^{[33]}$. More recently, a piperazine-linked benzimidazole derivative has been reported for its analgesic potential as TRPV-1 antagonist in a patent application from Amgen ${ }^{[34]}$. Inspired by these findings, the present investigation made a special focus on the analgesic activity displayed by the synthesized derivatives with an intention to explore the possibility of developing new analgesic agents.

The antidiarrheal activity of benzimidazole derivatives presents a slightly different scenario. Compared to other pharmacological activities, there have been a few reports about benzimidazole-based compounds with promising activity to control and treat gastrointestinal motility disorders, such as diarrhea. A patent by Cupps and Bogdan described the usefulness of substituted 5-(2- imidazolinylamino)benzimidazole derivatives for treating diarrhea and other functional bowel disorders by acting as alpha-2 adrenoceptor agonist and exerting antimotility and antisecretory effects on the gastrointestinal tract ${ }^{[35]}$. Rifaximin, a semisynthetic antibiotic derived from rifamycin was first introduced in Italy in 1987 and following its US FDA approval in 2004, the drug found its worldwide application for the treatment and prevention of traveler's diarrhea ${ }^{[36,37]}$. Even after the introduction of a benzimidazole derivative into clinical practice, not many studies have been carried out since then to explore the antidiarrheal potential of both novel and already reported benzimidazole derivatives. As a result, it was identified that the antidiarrheal activity displayed by the synthesized derivatives as an interesting and promising source of research. Considering the importance of synthetic drugs and medications in relief of pain and gastrointestinal disorders, herein a disclosure was made on the effects of the synthesized 1,2-disubstituted benzimidazole derivatives.

\section{MATERIALS AND METHODS}

\section{Chemistry:}

All reactions were carried out in well-dried glassware using magnetic stirrer. Chemicals and reagents such as, $o$-phenylenediamine, 4-chloro-o-phenylenediamine, benzaldehyde, 4-chlorobenzaldehyde, ammonium chloride, chloroform, $n$-hexane, ethyl acetate, sodium chloride, and sodium sulfate were purchased from Sigma-Aldrich, USA. Ethyl acetate and $n$-hexane were distilled over calcium hydride prior to use. For column chromatography (CC), silica gel $60(0.06$ $-0.2 \mathrm{~mm}$, Roth) was employed. ${ }^{1} \mathrm{H}$ NMR was recorded on a Jeol Alpha 400 spectrometer (operating at 400 $\mathrm{MHz}$ ) and a Bruker $400 \mathrm{MHz}$ spectrometer using $\mathrm{CDCl}_{3}$ as solvent and tetramethylsilane (TMS) as an internal reference standard. All chemical shift $(\delta)$ values were reported in parts per million (ppm), and spin-spin coupling constants, $J$, were expressed in Hz. IR spectra was recorded on a Shimadzu FTIR8400S spectrometer (Shimadzu Corporation, Japan). Thin layer chromatography (TLC) was performed on precoated plates of silica gel (silica gel 60 GF254, Sigma-Aldrich) to monitor the reactions.

\section{General procedure for the synthesis of benzimidazole derivatives:}

The synthetic pathway for disubstituted benzimidazole derivatives is depicted in Scheme 1. The substituted benzimidazole derivatives were synthesized by modification of a previously reported method ${ }^{[38]}$. At first, 1.0 equivalent of diamine compounds, 10.0 equivalents of aromatic aldehydes and 4.0 equivalents of ammonium chloride were taken in a round bottom flask and the resultant mixture was dissolved in $5 \mathrm{ml}$ of chloroform and stirred for $24 \mathrm{~h}$. The completion of the reaction was monitored by TLC 
www.ijpsonline.com

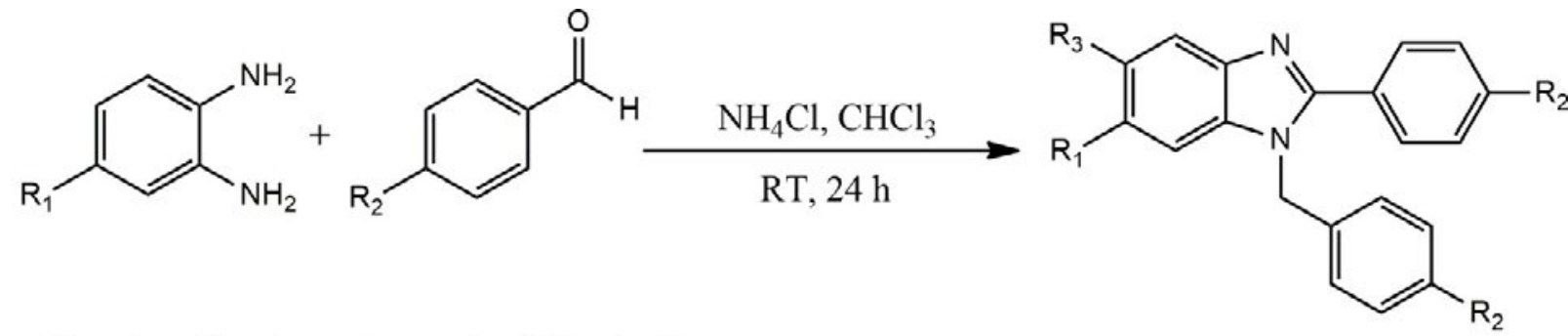

o-Phenylenediamine Aromatic aldehyde (2)

(1)

$$
\mathrm{R}_{1}=\mathrm{H} / \mathrm{Cl} \quad \mathrm{R}_{2}=\mathrm{H} / \mathrm{Cl}
$$

Disubstituted benzimidazole

(3a to 3d)

$$
\mathrm{R}_{1}, \mathrm{R}_{2}, \mathrm{R}_{3}=\mathrm{H} / \mathrm{Cl}
$$

Scheme 1: Synthesis of 1,2-disubstituted benzimidazole derivatives

1,2-disubstituted benzimidazole derivatives were synthesized by condensing $o$ - phenylenediamines with aromatic aldehydes. RT is room temperature

TABLE 1: 1,2-DISUBSTITUTED BENZIMIDAZOLES

\begin{tabular}{llllc}
\hline Product (3) & R1 & R2 & R3 & Isolated yield (\%) \\
\hline $3 \mathrm{a}$ & $\mathrm{H}$ & $\mathrm{H}$ & $\mathrm{H}$ & 73 \\
$3 \mathrm{~b}$ & $\mathrm{H}$ & $\mathrm{Cl}$ & $\mathrm{H}$ & 74 \\
$3 \mathrm{C}$ & $\mathrm{Cl}$ & $\mathrm{H}$ & $\mathrm{Cl}$ & $77(3 \mathrm{C}=42,3 \mathrm{~d}=35)$ \\
$3 \mathrm{~d}$ & $\mathrm{Cl}$ & $\mathrm{H}$ & $\mathrm{H}$ & \\
\hline
\end{tabular}

(eluent $n$-hexane: ethyl acetate-3:1). Later, the solvent was removed under reduced pressure using a rotary evaporator and the residue was extracted with ethyl acetate $(30 \mathrm{ml})$. The organic layer was washed with $10 \mathrm{ml}$ brine (sodium chloride) solution. The layers were separated and the organic layer was dried over sodium sulfate. Upon removal of the solvent under reduced pressure, the product was subjected to column chromatography using $n$-hexane and ethyl acetate in different ratios. A number of compounds $3 \mathrm{a}$ to $3 \mathrm{~d}$ were obtained (Table 1) which were taken for analytical tests for characterization.

\section{Benzyl-2-phenyl-1-H-benzimidazole (3a):}

IR $\left(\mathrm{KBr}, \mathrm{cm}^{-1}\right) 3083.31$ (C-H stretching of aromatic ring), 2958.9 (C-H stretching of aliphatic ring, 1450.52, 1391.89 (C-N stretching of imidazole ring). ${ }^{1} \mathrm{H}$ NMR (400 MHz, TMS, CDCl3, $\delta / \mathrm{ppm}): 5.46$ (s, 2H), 7.09 (d, $J=6.4 \mathrm{~Hz}, 2 \mathrm{H}), 7.24-7.35(\mathrm{~m}, 6 \mathrm{H}), 7.42-7.48$ (m, 3H), $7.71(\mathrm{dd}, J=1.2 \mathrm{~Hz}, 2 \mathrm{H}), 7.90(\mathrm{~d}, J=8 \mathrm{~Hz}$, $1 \mathrm{H})$. The above spectral data was compared with the reported data ${ }^{[26]}$ and the structure of the compound was confirmed as 1-benzyl-2-phenyl-1- $H$-benzimidazole.

1-(4-Chlorobenzyl)-2 -(4-chlorophenyl)-1-Hbenzimidazole ( $3 \mathrm{~b})$ :

IR (KBr, cm-1)- 3446.91 (C-H stretching of aromatic ring), 2928.04 (C-H stretching of aliphatic ring), 1683.91, $1591.33(\mathrm{C}=\mathrm{N}$ stretching of imidazole ring), 1250.88 (C-N stretching of imidazole ring). ${ }^{1} \mathrm{H}$ NMR (400 MHz, DMSO (d $\mathrm{d}_{6}$ ), $\delta / \mathrm{ppm}$ )- 5.59 (s, 2H), 7.00-7.02 (d, $J=8 \mathrm{~Hz}, 2 \mathrm{H}), 7.26-7.28(\mathrm{~m}, 2 \mathrm{H}), 7.34-7.37$ (dd, $J=8 \mathrm{~Hz}, 4 \mathrm{~Hz}, 2 \mathrm{H}), 7.48-7.51(\mathrm{~m}, 1 \mathrm{H}), 7.59-7.61$ (dd, $J=8 \mathrm{~Hz}, 4 \mathrm{~Hz}, 2 \mathrm{H}), 7.72-7.74(\mathrm{~d}, J=8 \mathrm{~Hz}, 1 \mathrm{H}), 7.73$ $-7.75(\mathrm{dd}, J=8 \mathrm{~Hz}, 4 \mathrm{~Hz}, 2 \mathrm{H})$. The above spectral data was compared with the reported data ${ }^{[26]}$ and the structure of the compound was confirmed as 1-(4-Chlorobenzyl)2-(4-chlorophenyl)-1- $H$-benzimidazole.

\section{Phenyl-1-benzyl-5-chloro-1- $\boldsymbol{H}$-benzimidazole (3c):}

IR (KBr, cm-1)- 3446.91 (C-H stretching of aromatic ring), 1457.27, 1390.72 (C-N stretching of imidazole ring). 1H NMR (400 MHz, TMS, DMSO (d6), $\delta / \mathrm{ppm})$ : $5.62(\mathrm{~s}, 2 \mathrm{H}), 7.00(\mathrm{dd}, J=6 \mathrm{~Hz}, 12 \mathrm{~Hz}, 2 \mathrm{H}), 7.25-$ $7.31(\mathrm{~m}, 4 \mathrm{H}), 7.52-7.56(\mathrm{~m}, 4 \mathrm{H}), 7.73-7.76(\mathrm{~m}, 2 \mathrm{H})$, $7.81(\mathrm{~d}, J=1.2 \mathrm{~Hz}, 1 \mathrm{H})$. This spectral data was found to be identical with the published data ${ }^{[39]}$ and the structure of the compound was confirmed as 1-Benzyl-2-phenyl5-chloro-1- $H$-benzimidazole.

\section{1-Benzyl-2-phenyl-6-chloro-1-H-benzimidazole (3d):}

IR (KBr, cm-1)- 3565.53, 3414.12 (C-H stretching of aromatic ring), 2917.43 (C-H stretching of aliphatic ring), 1688.73, $1636.65(\mathrm{C}=\mathrm{N}$ stretching of imidazole ring). 1274.03 (C-N stretching of imidazole ring). 1H NMR (400 MHz, TMS, DMSO (d6), $\delta / \mathrm{ppm})-5.61$ (s, 2H), 6.97-6.98 (d, J=6 Hz, 2H), 7.24-7.29 (m, 4H), 7.52-7.55 (m, 3H), 7.65-7.75 (m, 4H). This spectral data was compared with the reported data ${ }^{[40]}$ and the structure of the compound was confirmed as 1-benzyl2-Phenyl-6-chloro-1- $H$-benzimidazole.

\section{Screening of analgesic activity:}

The in vivo analgesic activity of the synthesized compounds was assessed using the acetic acid-induced writhing method (peripheral analgesia) in Swiss albino mice (Mus musculus $)^{[41,42]}$. Mice of either sex, 
of 4-5 w old, were obtained from the animal house of Jahangirnagar University. The animals were housed in polypropylene cages $(30 \times 20 \times 13 \mathrm{~cm})$ under standard conditions $\left(21 \pm 1^{\circ}\right.$ with a $12 \mathrm{~h}$ light and dark cycle $)$ for $7 \mathrm{~d}$ before the experiment. The animals were fed with standard diet and water was provided ad libitum. Diet was stopped $12 \mathrm{~h}$ prior to the experiment. As these animals were very sensitive to environmental changes, they were kept for at least 3-4 d before the test in the environment where the experiment would take place. All ethical matters for the use of experimental animals were considered carefully.

Fifty mice were randomly selected and divided into 10 groups denoted as control, standard, 3a (d1), 3a $(\mathrm{d} 2), 3 \mathrm{~b}(\mathrm{~d} 1), 3 \mathrm{~b}(\mathrm{~d} 2), 3 \mathrm{c}(\mathrm{d} 1), 3 \mathrm{c}(\mathrm{d} 2), 3 \mathrm{~d}(\mathrm{~d} 1)$ and $3 \mathrm{~d}$ (d2) consisting of 5 mice in each group. Each group received a particular treatment (lower dose, d1 = $25 \mathrm{mg} / \mathrm{kg}$ and higher dose, $\mathrm{d} 2=50 \mathrm{mg} / \mathrm{kg}$ ). Prior to any treatment, each mouse was weighed properly and the doses of the test samples, standard aceclofenac and control were adjusted accordingly. After $40 \mathrm{~min}$, acetic acid $(0.7 \%)$ was administered intraperitoneally at a dose of $0.1 \mathrm{ml} / 10 \mathrm{~g}$ to each animal of all the groups to produce writhes. After 5 min of its administration, the number of squirms or writhings was counted for each mouse for $15 \mathrm{~min}$. The responses of the test samples and aceclofenac treated groups were compared to those of the animals in the control group. Percent inhibition of writhing in comparison to control group was taken as an index of analgesia and was calculated using the following formula: $\%$ inhibition $=(\mathrm{Wc}-\mathrm{Wt}) \times 100) / \mathrm{Wc}$, where $\mathrm{Wc}$ is the average number of writhing reflexes in the control group and $\mathrm{Wt}$ is the average number of writhing reflexes in the test group.

\section{Screening of antidiarrheal activity:}

Antidiarrheal activity of the synthesized benzimidazole derivatives was tested using castor oil-induced diarrhea in Swiss albino mice ${ }^{[43]}$. Mice of either sex (4-5 w old) were used in this experiment. The mice were divided into 10 groups of five mice each. The animals were divided into control, standard and test groups ( $\mathrm{d} 1=25 \mathrm{mg} / \mathrm{kg}$ and $\mathrm{d} 2=50 \mathrm{mg} / \mathrm{kg}$ dose $)$. Control groups received normal saline ( $1 \%$ Tween 80 in normal saline) while the standard group received loperamide. After oral administration of the samples, an interval of $30 \mathrm{~min}$ was given for proper absorption of the samples. Then $0.5 \mathrm{ml}$ of castor oil was given orally to mice in all the groups. Each mouse was kept in an individual cage. The floor lining was changed every hour. The total number of defecation for each mouse was counted up to $4 \mathrm{~h}$ and then the data was evaluated statistically to find its significance. The percent inhibition of defecation was calculated using the following formula, $\%$ inhibition of defecation $=(1-B / A) \times 100$, where $A$ is the mean number of defecations produced by castor oil, $\mathrm{B}$ is the mean number of defecations after standard or test sample treatment. The observations of the experimental groups were compared to that of the control and standard to evaluate the antidiarrheal activity of the samples.

\section{Statistical analysis:}

All values were expressed as the mean \pm standard error of the mean (SEM) and the results were analyzed using the One Way Analysis of Variance (ANOVA) followed by Dunnett's test by using Graph Pad software. $\mathrm{P}<0.05$ was considered to be statistically significant.

\section{RESULTS AND DISCUSSION}

1,2-disubstituted benzimidazoles were synthesized via condensation of $o$-phenylenediamines with several aldehydes. Initially, for selective synthesis of 1,2-disubstituted benzimidazoles, reaction conditions were optimized using $o$-phenylenediamine (OPD) and benzaldehyde. This condensation reaction was carried out under diverse reaction conditions by increasing the equivalent amount of benzaldehyde, temperature and reaction time and the most suitable condition for the highest yield of disubstituted benzimidazoles was identified (Table 2). When benzaldehyde and $o$-phenylenediamine were condensed in room temperature in 1:1 equivalent amount for $24 \mathrm{~h}$

\section{TABLE 2: REACTION OPTIMIZATION AND YIELD}

\begin{tabular}{|c|c|c|c|c|c|c|}
\hline \multirow{2}{*}{ OPD mol (Compound 1) } & \multirow{2}{*}{$\begin{array}{l}\text { Benzaldehyde mmol } \\
\text { (Compound } 2)\end{array}$} & \multirow{2}{*}{$\begin{array}{l}\text { Equivalents } \\
\qquad(1: 2)\end{array}$} & \multirow{2}{*}{$\begin{array}{l}\text { Reaction } \\
\text { conditions }\end{array}$} & \multicolumn{3}{|c|}{ Yield (\%) } \\
\hline & & & & $3 a$ & $4 a$ & Total \\
\hline 1.97 & 1.97 & $1: 1$ & RT, 24 h & 12 & 65 & 77 \\
\hline 1.97 & 5.91 & $1: 3$ & RT, $24 \mathrm{~h}$ & 37 & 53 & 90 \\
\hline 1.97 & 9.85 & $1: 5$ & RT, $24 \mathrm{~h}$ & 51 & 36 & 87 \\
\hline 1.97 & 19.7 & $1: 10$ & RT, 24 h & 73 & 15 & 88 \\
\hline 1.97 & 19.7 & $1: 10$ & $60^{\circ}, 48 \mathrm{~h}$ & 55 & 19 & 74 \\
\hline 1.97 & 19.7 & $1: 10$ & $90^{\circ}, 48 \mathrm{~h}$ & 41 & 14 & 55 \\
\hline
\end{tabular}

OPD is o-phenylenediamine, RT is room temperature 


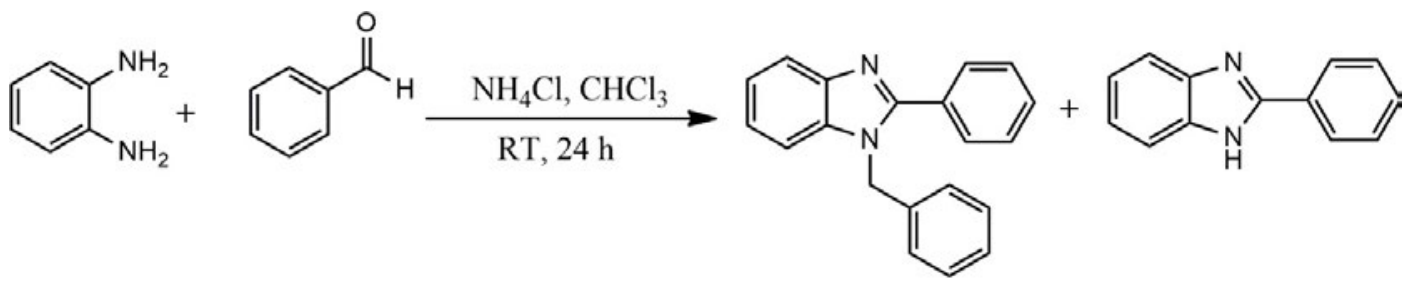

OPD (1) Benzaldehyde (2)

1-Benzyl-2-phenyl-

$1 H$-benzimidazole (3a)
2-Phenyl-1 $H$ -

benzimidazole (4a)

Fig. 1: Condensation between $o$-phenylenediamine and benzaldehyde

Both starting material used in 1:1 equivalent. RT is room temperature

(fig. 1), monosubstituted derivative 4a was the major product (65\% yield, Table 2$)$ and the minor product was the disubstituted benzimidazole derivative, 3a (12\% yield,). Upon increasing the amount of benzaldehyde to 3 equivalents of $o$-phenylenediamine, the yield of $3 \mathrm{a}$ was increased (37\% yield). Further increment of benzaldehyde resulted in the formation of the disubstituted derivative as the major product. Good yield $(73 \%)$ of 3 a was obtained using excess (10 equivalents) amount of benzaldehyde. The yield value of the condensation reaction was also monitored in increased temperature using different reaction time. When the reaction was performed at $60^{\circ}$ and $90^{\circ}$ for $48 \mathrm{~h}$ the yield value of $3 \mathrm{a}$ was decreased to 55 and $41 \%$, respectively presumably due to the degradation of the desired products ${ }^{[44]}$. In the evaluation of the pharmacological properties, both monosubstituted and disubstituted derivatives were screened initially. However, the monosubstituted derivatives (4a, fig. 1) displayed inferior activity compared to their disubstituted counterparts. Therefore, the results of biological evaluation of the monosubstituted derivatives was not shown. In peripheral analgesic activity, the disubstituted derivatives decreased the number of acetic acid-induced writhings in mice. The compounds $3 \mathrm{a}, 3 \mathrm{~b}$, and $3 \mathrm{c}$ displayed promising analgesic activity (\% inhibition of $69.40,64.93$ and 88.81 , respectively) at a dose of $25 \mathrm{mg} / \mathrm{kg}$, which was comparable to that produced by $25 \mathrm{mg} / \mathrm{kg}$ aceclofenac $(88.81 \%)$. Analgesic activity of $3 \mathrm{c}$ was found to be equal to that of aceclofenac. At $50 \mathrm{mg} / \mathrm{kg}$ dose, 3a, 3b, and 3c inhibited writhings to the extent of $73.88,77.61$ and $89.55 \%$, respectively. Compound $3 \mathrm{~d}$, at $50 \mathrm{mg} / \mathrm{kg}$ exhibited mild analgesic activity with $47.01 \%$ inhibition. The results are summarized in Table 3 . The abdominal constriction response produced by acetic acid is a sensitive method for establishing nociception in experimental animals. The response is believed to involve local peritoneal macrophages and mast cells which release cytokines, e.g. tumor necrosis factor $\alpha(\mathrm{TNF}-\alpha)$, interleukin $1 \beta$ (IL-1 $\beta$ ) and interleukin 8 (IL-8) and is regulated by the

\begin{tabular}{|c|c|c|c|}
\hline $\begin{array}{l}\text { TABLE } \\
\text { DISUBS } \\
\text { ON TH } \\
\text { MICE }\end{array}$ & $\begin{array}{l}\text { 3: } \text { ANALGES } \\
\text { TITUTED BENZIMID } \\
\text { ACETIC ACID-IND }\end{array}$ & $\begin{array}{l}\text { ACTI } \\
\text { ZOLE D } \\
\text { CED WR }\end{array}$ & $\begin{array}{l}\text { ITY OF } \\
\text { RIVATIVES } \\
\text { 'HINGS IN }\end{array}$ \\
\hline $\begin{array}{l}\text { Sample } \\
\text { code }\end{array}$ & $\begin{array}{l}\text { Number of writhings } \\
(\text { mean } \pm \text { SEM })^{\mathrm{a}}\end{array}$ & $\begin{array}{c}\text { Writhings } \\
(\%)\end{array}$ & $\begin{array}{c}\text { Inhibition } \\
(\%)\end{array}$ \\
\hline$\overline{C S}$ & $26.80 \pm 1.53$ & 100 & - \\
\hline SS & $3.00 \pm 0.71$ & 11.19 & 88.81 \\
\hline $3 a(d 1)$ & $8.20 \pm 1.56^{*}$ & 30.60 & 69.4 \\
\hline $3 a(d 2)$ & $7.00 \pm 1.30^{*}$ & 26.12 & 73.88 \\
\hline $3 b(d 1)$ & $9.40 \pm 1.81^{*}$ & 35.07 & 64.93 \\
\hline $3 b(d 2)$ & $6.00 \pm 1.30^{*}$ & 22.39 & 77.61 \\
\hline $3 c(d 1)$ & $3.00 \pm 0.71^{*}$ & 11.19 & 88.81 \\
\hline $3 c(d 2)$ & $2.80 \pm 0.66^{*}$ & 10.45 & 89.55 \\
\hline 3d (d1) & $19.00 \pm 0.71^{*}$ & 70.90 & 29.10 \\
\hline $3 d(d 2)$ & $14.20 \pm 1.16^{*}$ & 52.99 & 47.01 \\
\hline
\end{tabular}

aEach value represents the mean $\pm S E M,(n=5),{ }^{*} P<0.05$ compared to control. CS is control sample; SS is standard aceclofenac, $25 \mathrm{mg} / \mathrm{kg}$, d1 is lower dose $25 \mathrm{mg} / \mathrm{kg}$, d2 is higher dose $50 \mathrm{mg} / \mathrm{kg}$

prostaglandin pathways ${ }^{[45]}$. The antinociceptive effect produced by the benzimidazole derivatives in this study was comparable to that of standard aceclofenac, an NSAID. This category of drugs produce action primarily by blocking prostaglandin synthesis through the inhibition of COX enzyme, specifically COX-2 for aceclofenac ${ }^{[46]}$. The synthesized compounds might have analgesic potentials that could interfere with the prostaglandin pathways and therefore have the potential to be developed as NSAIDs to relieve pain. In the evaluation of antidiarrheal property, the compounds $3 \mathrm{a}$ and $3 \mathrm{~d}$ exhibited significant activity in mice $(\%$ of inhibition of defecation 56.45 and 67.64, respectively) at a dose level of $25 \mathrm{mg} / \mathrm{kg}$ which was comparable to that obtained by standard loperamide $(85.48 \%$ of inhibition of defecation at $25 \mathrm{mg} / \mathrm{kg}$ ). At $50 \mathrm{mg} / \mathrm{kg}$, $3 \mathrm{a}$ and $3 \mathrm{~d}$ displayed improved diarrheal inhibition (75.81 and $80.65 \%$, respectively). Compounds $3 \mathrm{~b}$ and $3 \mathrm{c}$ also showed notable antidiarrheal activity at $50 \mathrm{mg} / \mathrm{kg}$ ( 66.13 and $64.52 \%$, respectively). It is evident that the antidiarrheal property of all the derivatives was increased significantly upon the increasing the dose level. The results of antidiarrheal activity are summarized in Table 4. 


\section{TABLE 4: ANTIDIARRHEAL ACTIVITY OF SYNTHESIZED BENZIMIDAZOLE DERIVATIVES ON CASTOR OIL-INDUCED DIARRHEA}

\begin{tabular}{lcc}
\hline $\begin{array}{l}\text { Sample } \\
\text { code }\end{array}$ & $\begin{array}{c}\text { Number of stool pellets of } \\
\text { 5 mice in 4 h (mean } \pm \text { SEM) }\end{array}$ & $\begin{array}{c}\text { \% Inhibition of } \\
\text { defecation }\end{array}$ \\
\hline CS & $12.40 \pm 0.51$ & \\
SS & $1.80 \pm 0.37^{*}$ & 85.48 \\
3a (d1) & $5.40 \pm 0.87^{*}$ & 56.45 \\
3a (d2) & $3.00 \pm 0.45^{*}$ & 75.81 \\
3b (d1) & $9.00 \pm 1.14^{* *}$ & 27.42 \\
3b (d2) & $4.20 \pm 0.58^{*}$ & 66.13 \\
3c (d1) & $7.00 \pm 0.55^{* *}$ & 43.55 \\
3c (d2) & $4.40 \pm 0.40^{*}$ & 64.52 \\
3d (d1) & $4.00 \pm 0.45^{*}$ & 67.74 \\
3d (d2) & $2.40 \pm 0.51^{*}$ & 80.65
\end{tabular}

beach value represents the mean \pm SEM, $(n=5),{ }^{*} \mathrm{P}<0.05$ compared with control CS is control sample; SS is standard loperamide, $25 \mathrm{mg} /$ $\mathrm{kg}$, d1 is lower dose $25 \mathrm{mg} / \mathrm{kg}, \mathrm{d} 2$ is higher dose $50 \mathrm{mg} / \mathrm{kg}$

Castor oil has the inherent property of inducing diarrhea in experimental animals. Upon hydrolysis of castor oil, ricinoleic acid and ricinoleate salts are formed ${ }^{[47]}$, which are responsible for the hypersecretory response of water and electrolytes stimulating adenyl cyclase and prostaglandin secretion from intestinal epithelial cells ${ }^{[48]}$. The antidiarrheal activity produced by the 1,2-disubstituted benzimidazoles in the presentstudywas comparable to that of loperamide, which is commonly used in the treatment of diarrhea. Loperamide, an opioidreceptor agonist, acts on the $\mu$-opioid receptors located in the myenteric plexus of the large intestine leading to decreased activity of the myenteric plexus and reduced longitudinal and circular smooth muscles tone of the intestinal wall ${ }^{[49]}$. The antagonism by benzimidazole derivatives of castor oil-induced diarrhea might involve the reduction in the severity of inflammatory changes in the intestinal wall ${ }^{[43]}$. They could interfere with the motor function and absorption rate from the intestine by acting on the $\mu$-opioid receptors in the large intestine to produce antidiarrheal effect and they have the potential to be developed as antidiarrheal drugs like loperamide. In conclusion, preferential synthesis of the 1,2-disubstituted benzimidazole derivatives (3a-3d) from $o$-phenylenediamines and aldehydes by a simple, inexpensive and easy method was accomplished. All compounds demonstrated remarkable analgesic and antidiarrheal properties amongst which the derivative $3 \mathrm{a}$ appeared to be the most promising agent. To the best of our knowledge, this is the first report of analgesic and antidiarrheal potentials of the synthesized derivatives. These derivatives could serve as lead compounds for designing and developing novel, potent and safe antidiarrheal and analgesic agents.

\section{ACKNOWLEDGEMENTS}

The authors are highly grateful to the Institute of Food and Nutrition, University of Dhaka, Bangladesh for animal husbandry throughout the research. Poushali Saha expresses gratitude to the Ministry of Science and Technology, Government of the People's Republic of Bangladesh for providing financial support through National Science and Technology (NST) Fellowship (Fellowship No. 39.00.0000.012.002.03.18-561 ${ }^{[26]}$ ).

\section{REFERENCES}

1. El Rashedy AA, Aboul-Enein HY. Benzimidazole derivatives as potential anticancer agents. Mini Rev Med Chem 2013;13(3):399-407.

2. Luo YL, Baathulaa K, Kannekanti VK, Zhou CH, Cai GX. Novel benzimidazole derived naphthalimide triazoles: synthesis, antimicrobial activity and interactions with calf thymus DNA. Sci China Chem 2015;58(3):483-94.

3. Prasad PMK, Sundararajan R. Design, synthesis, antitubercular and antimicrobial activities of novel thiazole substituted benzimidazole derivatives. Der Pharm Lett 2017;9(6):270-84.

4. Monforte AM, De Luca L, Buemi MR, Agharbaoui FE, Pannecouque C, Ferro S. Structural optimization of N1-arylbenzimidazoles for the discovery of new non-nucleoside reverse transcriptase inhibitors active against wild-type and mutant HIV-1 strains. Bioorg Med Chem 2018;26(3):661-74.

5. Gaba M, Singh D, Singh S, Sharma V, Gaba P. Synthesis and pharmacological evaluation of novel 5- substituted1-(phenylsulfonyl)-2-methylbenzimidazole derivatives as anti-inflammatory and analgesic agents. Eur J Med Chem 2010;45(6):2245-49.

6. Kumar N, Sharma CS, Ranawat MS, Singh HP, Chauhan LS, Dashora, N. Synthesis, analgesic and anti- inflammatory activities of novel mannich bases of benzimidazoles. J Pharm Investig 2015;45:65-71.

7. Kuş C, Ayhan-Kılcıgil G, Özbey S, Kaynak FB, Kaya M, Çoban $\mathrm{T}$, et al. Synthesis and antioxidant properties of novel N-methyl-1,3,4-thiadiazol-2-amine and 4-methyl-2H-1,2,4triazole-3 $(4 \mathrm{H})$-thione derivatives of benzimidazole class. Bioorg Med Chem 2008;16(8):4294-303.

8. Menteşe E, Yılmaz F, Baltaş N, Bekircan O, Kahveci B. Synthesis and antioxidant activities of some new triheterocyclic compounds containing benzimidazole, thiophene, and 1,2,4-triazole rings. J Enzyme Inhib Med Chem 2015;30(3):435-41

9. Singla P, Luxami V, Paul K. Triazine-benzimidazole hybrids: Anticancer activity, DNA interaction and dihydrofolate reductase inhibitors. Bioorg Med Chem 2015;23(8):1691-700.

10. Bhambra AS, Edgar M, Elsegood MRJ, Horsburgh L, Kryštof $\mathrm{V}$, Lucas PD, et al. Novel fluorinated benzimidazole-based scaffolds and their anticancer activity in vitro. J Fluor Chem 2016;188:99-109.

11. Ashok D, Gundu S, Aamate VK, Devulapally MG. Conventional and microwave-assisted synthesis of new indoletethered benzimidazole-based 1,2,3-triazoles and evaluation of their antimycobacterial, antioxidant and antimicrobial activities, Mol Divers 2018;22(4):769-78.

12. Hernández-Luis F, Hernández-Campos A, Castillo R, Navarrete-Vázquez G, Soria-Arteche O, HernándezHernández M, et al. Synthesis and biological activity of 
2-(trifluoromethyl)-1H- benzimidazole derivatives against some protozoa and Trichinella spiralis. Eur J Med Chem 2010;45(7):3135-41.

13. Maske PP, Lokapure SG, Nimbalkar D, Disouza JI. Synthesis and antiprotozoal activity of nitro and halogeno substituted some novel mercaptobenzimidazole derivatives. Der Pharma Chem 2012;4(3):1283-87.

14. Sharma MC, Kohli DV, Sharma S. Benzimidazoles derivatives with (2-\{6-Chloro-5-nitro-1-[2-(1H- tetrazol-5-yl) biphenyl4-ylmethyl] 1H-benzoimidazol-2-yl\}-phenyl)-(substitutedbenzylidene)-amine with potential angiotensin II receptor antagonists as antihypertensive activity. Int $\mathrm{J}$ Drug Deliv 2010;2(3):228-37.

15. Hao LP, Xue WZ, Han XF, He X, Zhang J, Zhou ZM. Design, synthesis and biological activity of 4'- [(benzimidazol-1-yl) methyl]biphenyl-2-sulphonamides as dual angiotensin II and endothelin A receptor antagonists. Med Chem Commun 2015;6(4):715-18.

16. Ushiroda K, Maruta K, Takazawa T, Nagano T, Taiji M, Kohno $\mathrm{T}$, et al. Synthesis and pharmacological evaluation of novel benzoylazole-based PPAR $\alpha / \gamma$ activators. Bioorg Med Chem Lett 2011;21(7):1978-82.

17. Özil M, Emirik M, Beldüz A, Ülker S. Molecular docking studies and synthesis of novel bisbenzimidazole derivatives as inhibitors of $\alpha$-glucosidase. Bioorg Med Chem 2016;24(21):5103-14.

18. Bhrigu B, Siddiqui N, Pathak D, Alam MS, Ali R, Azad B. Anticonvulsant evaluation of some newer benzimidazole derivatives: Design and synthesis. Acta Pol Pharm - Drug Res 2012;69(1):53-62.

19. Hauel NH, Nar H, Priepke H, Ries U, Stassen JM, Wienen W. Structure-Based Design of Novel Potent Nonpeptide Thrombin Inhibitors. J Med Chem 2002;45(9):1757-66.

20. Rao A, Chimirri A, Clercq ED, Monforte AM, Monforte P, Pannecouque $\mathrm{C}$, et al. Synthesis and anti- HIV activity of 1-(2,6-difluorophenyl)-1H,3H-thiazolo[3,4-a]benzimidazole structurally-related 1,2-substituted benzimidazoles. Il Farmaco 2002;57(10):819-23.

21. Salehi P, Dabiri M, Zolfigol MA, Otokesh S, Baghbanzadeh M. Selective synthesis of 2-aryl-1- arylmethyl-1H-1,3benzimidazoles in water at ambient temperature. Tetrahedron Lett 2006;47(15):2557-60.

22. Ayhan-Kılcıgil G, Kus C, Özdamar ED, Can-Eke B, Iscan M. Synthesis and Antioxidant Capacities of Some New Benzimidazole Derivatives. Arch Pharm (Weinheim) 2007;340(11):607-11.

23. Gowda NR, Kavitha CV, Chiruvella KK, Joy O, Rangappa KS, Raghavan SC. Synthesis and biological evaluation of novel 1-(4-methoxyphenethyl)-1H-benzimidazole-5-carboxylic acid derivatives and their precursors as antileukemic agents. Bioorg Med Chem Lett 2009;19(16):4594-600.

24. Borhade AV, Tope DR, Patil DR. An efficient synthesis of Benzimidazole by cyclization-oxidation processes using $\mathrm{Fe} /$ $\mathrm{MgO}$ as a heterogeneous recyclable catalyst. J Chem Pharm Res 2012;4:2501-06.

25. Yuksek D, Algul O, Dögen A, Tari O, Kucuk E, Otag ZF, et al. Synthesis and antimicrobial activity evaluation of some benzimidazole and indole derivatives. Afr J Microbiol Res 2013;7(17):1708-15.

26. Mohammadizadeh MR, Taghavi SZ. Trifluoroacetic Acid as an Efficient Catalyst for the Room Temperature Synthesis of 2-Aryl-1-arylmethyl-1H-1,3-benzimidazoles in Aqueous Media. E-Journal Chem 2011;8(1):101-06.
27. Qian K, Nian X, Zhu GM, Cui DM, Zhang C. Nano ZnO Catalysed One-pot Synthesis of Benzimidazoles from o-phenylenediamine with Aldehydes. Asian J. Chem 2015;27(11):4045-48.

28. Trepanier LA. Mechanisms of drug-associated hepatotoxicity in the dog and cat, in: Proceedings of the 20th annual forum of the ACVIM, Dallas, 2002, pp. 669-671.

29. Meek IL, Van de Laar MAFJ, Vonkeman HE. Non-steroidal anti-inflammatory drugs: an overview of cardiovascular risks. Pharmaceuticals (Basel) 2010;3(7):2146-62.

30. Gaba M, Singh S, Mohan C. Benzimidazole: an emerging scaffold for analgesic and anti-inflammatory agents. Eur J Med Chem 2014;76:494-505.

31. Admiraal PV, Knape H, Zegveld C. Experience with bezitramide and droperidol in the treatment of severe chronic pain. Br J Anaesth 1972;44:1191-96.

32. Kay B. A study of strong oral analgesic: the relief of postoperative pain using dextromoramide pentazoeine and bezitramide. Br J Anaesth 1973;45:623-28.

33. Meijer DKF, Hovinga G, Versluis A, Bröring J, van Aken $\mathrm{K}$, Moolenaar $\mathrm{F}$, et al. Pharmacokinetics of the oral narcotic analgesic bezitramide and preliminary observations on its effect on experimentally induced pain. Eur J Clin Pharmacol 1984;27:615-618.

34. Rami HK, Gunthorpe MJ. The therapeutic potential of TRPV1 (VR1) antagonists: clinical answers await. Drug Discov Today: Ther Strateg 2004;1(1):97-104.

35. Cupps TL, Bogdan SE, inventors; Procter, Gamble Co, assignee. 5-(2-imidazolinylamino) benzimidazole compounds useful as alpha-2 andrenoceptor agonists. United States patent US 5,541,210. 1996 Jul 30.

36. Gobernado M, Ponce J. Rifaximina. Rev Esp Quimioter 2004;17(2):141-53.

37. DuPont HL. Therapy for and prevention of traveler's diarrhea. Clin Infect Dis 2007;45 Suppl 1:S78-84.

38. Nannapaneni DT, Gupta AVSSS, Reddy MI, Sarva RC. Synthesis, Characterization, and Biological Evaluation of Benzimidazole Derivatives as Potential Anxiolytics. J Young Pharm 2010;2(3):273-79.

39. Hu JR, Zhang WJ, Zheng DG. A one-pot synthesis of bisarylhydrazones by $\mathrm{Cu}(\mathrm{I})$-catalyzed aerobic oxidation. Tetrahedron 2013;69(46):9865-69.

40. Sadig JR, Foster RA, Wakenhut F, Willis MC. PalladiumCatalyzed Synthesis of Benzimidazoles and quinazolinones from common precursors. J Org Chem 2012;77(21):9473-86.

41. Whittle $\mathrm{B}$. The use of changes in capillary permeability in mice to distinguish between narcotic and nonnarcotic analgesics. $\mathrm{Br}$ J Pharmacol Chemother 1964;22(2):246-53.

42. Collier HOJ, Dinneen LC, Johnson CA, Schneider C. The abdominal constriction response and its suppression by analgesic drugs in the mouse. Br J Pharmacol Chemother 1968;32(2):295-310.

43. Awouters F, Niemegeers CE, Lenaerts FM, Janssen PJ. Delay of castor oil diarrhoea in rats: a new way to evaluate inhibitors of prostaglandin biosynthesis. J Pharm Pharmacol 1978;30(1):41-5.

44. Some minor unidentified by-products were seen on the TLC which could not be isolated and characterized.

45. Ribeiro RA, Vale ML, Thomazzi SM, Paschoalato ABP, Poole $\mathrm{S}$, Ferreira $\mathrm{SH}$, et al. Involvement of resident macrophages and mast cells in the writhing nociceptive response induced by zymosan and acetic acid in mice. Eur $\mathrm{J}$ Pharmacol 2000;387(1):111-8. 
46. Cashman JN. The mechanisms of action of NSAIDs in analgesia. Drugs 1996;52(Suppl 5):13-23.

47. Iwao I, Terada Y. On the mechanism of diarrhea due to castor oil. Jpn J Pharmacol 1962;12:137-45.

48. Watson WC, Gordon RS. Studies on the digestion, absorption and metabolism of castor oil. Biochem Pharmacol 1962;11(3):229-36.

49. di Bosco AM, Grieco P, Diurno MV, Campiglia P, Novellino E, Mazzoni O. Binding site of loperamide: automated docking of loperamide in human mu- and delta-opioid receptors. Chem Biol Drug Des. 2008;71(4):328-35. 